\title{
Introduction of Fertigation in Sugarcane Production for Optimization of Water and Fertilizers Use
}

\author{
Daffa Alla Mohamed Abdel Wahab \\ Agricultural Engineering Section, Research and Development Department, Kenana Sugar Company, Rabak City, \\ Sudan \\ Email: dafaalla.rabih@kenana.com
}

Received 9 July 2014; revised 13 August 2014; accepted 7 September 2014

Copyright (C) 2014 by authors and Scientific Research Publishing Inc.

This work is licensed under the Creative Commons Attribution International License (CC BY). http://creativecommons.org/licenses/by/4.0/

\section{Open Access}

\begin{abstract}
A fertigation experiment was conducted during 2009/2010 and 2010/2011 seasons under commercial field conditions in Kenana Sugar Scheme, Sudan (latitude 13.10'N and longitude 32.40'E) in heavy clay soils, with $65 \%$ clay, $24 \%$ silt, $11 \%$ sand and pH $7.5-8.5$. The primary objective of this study was to compare different strategies for timing of injection, to develop management practices on the efficient use of water and fertilizers in production of sugarcane, maximize yield, and improve quality. In both seasons four treatments were studied in a randomized complete block design with three replications as: Injection of the dissolved urea $(46 \% \mathrm{~N})$ during entire irrigation time $(100 \%)$, during the first half of the irrigation time, during the second half of the irrigation time, and Mechanical application of urea. The first three treatments were applied with the third irrigation cycle through the irrigation water so that nitrogen fertilizer in form of dissolved urea $(46 \% \mathrm{~N})$ was injected in irrigation water by means of pressure differential tank system which is based on the principle of a pressure differential being created by a valve and flow regulator forcing and injecting a varying amount of dissolved fertilizer into the irrigation water. In the fourth treatment the fertilizer spreader and rigid tine cultivator were used for urea application just before the third irrigation event. The reference evapotranspiration (ETo) and the amount of water required for irrigating sugarcane plants were calculated according to its phenological stages using Peman-Monteith approach. The results of this study support the general finding that the injection during the entire irrigation $(100 \%$ of the irrigation) produced the best distribution uniformity of added urea. In this study, injection during the first half of the irrigation was not statistically different from injection during $100 \%$ of the irrigation.
\end{abstract}

\section{Keywords}

Irrigation, Injection, Fertigation, Randomized, Sugarcane, Gated Pipe, Hydro-Flume, 


\section{Introduction}

Sugarcane being a giant crop producing huge quantity of biomass generally demands higher amounts of nutrient elements [1]. A large number of research experiments have clearly demonstrated that for producing higher cane and sugar yields on a sustainable basis application of adequate amounts of fertilizer nutrients viz. nitrogen, phosphorous and potassium is essential. Sugarcane is a high bio-mass producer in a sense that it is one of the most photo-synthetically efficient $\mathrm{C}_{4}$ plants. [2] reported that sugarcane can remove about $300 \mathrm{~kg}$ nitrogen/ha/season from the soil (126 Kg itrogen/feddan/season).

[3] stated that the nitrogen requirement of sugarcane at Pongola in South Africa is greatest during the tillering (formative) phase. This is required for adequate tiller production and canopy development. Tillering in field grown sugarcane commences around 30 to 45 days after planting. Therefore, adequate $\mathrm{N}$ supply should be made available to the crop in the soil from the start of tillering phase. Further, [4] speculated that the crop requirement for $\mathrm{N}$ is higher in early grand growth period. This facilitates cane formation, checks tiller mortality and promotes cane growth. Application of more nitrogen at later phase of active crop growth period not only promotes late tiller formation, but also affects sugar recovery due to reduced juice sucrose percent, increase in soluble $\mathrm{N}$ in juice, water shoot formation besides attracting pests and diseases.

Application of commercial fertilizers is an economic necessity on many soils to promote crop production with nitrogen, phosphorous and potassium being the common fertilizer elements [5]. Nitrogen promotes rapid succulent growth; phosphorus gives early root growth, blooming, and resistance to pest and weather damage. Potassium lends toughness and strength and pest resistance to plants [6].

Significant benefits from fertigation cannot be expected unless the irrigation system design is optimized to meet local soil conditions [7] and this should be the first consideration when appraising fertigation strategies for poor soils.

Fertigation using furrow irrigation is a cost-effective and simple method of applying fertilizer across the field. In the past, fertigation has been associated with micro-irrigation and sprinkler irrigation systems. Injecting nitrogen into irrigation water has become increasingly common for producers using surface irrigation. Potentially, fertigation enables surface irrigation producers a means to more readily attain recommended nitrogen management guidelines aimed at minimizing nitrogen losses from agricultural fields. Moreover, Beth and Filters [8] revealed that fertigation allows growers to apply nutrients in small amounts throughout the season in response to crop needs without the potential crop damage or soil compaction caused by machinery application methods.

The introduction of fertigation technology (combined irrigation and fertilization) in modern agriculture opened up new possibilities for optimal water and nutrient supplies to crops and maintaining the desired concentration and distribution of ions and water in the soil. Fertigation is a key factor in modern intensive irrigated agriculture and can be practices under flood, furrow, and sprinkler irrigation [9]. At the same time, the costs of chemical fertilizers have increased and there is a need to improve fertilizer use efficiency for more benefits. The best answer to this challenge is "Fertigation", where both water and fertilizers are delivered to crop simultaneously through an irrigation system. Fertigation ensures that essential nutrients are supplied precisely at the area of most intensive root activity according to the specific requirements of sugarcane crop and type of soil resulting in higher cane yields and sugar recovery.

Playán and Faci [10] stated that when applying fertilizers through a fertigation system, there are several benefits. Applications can be targeted to specific areas, less equipment is used and fertilizer is applied into the soil, where it will be most effective. This means fertilizer can be applied at a lower rate and be more efficient and inexpensive to suit the exact needs of the plant. With fertigation, compaction due to equipment travel is eliminated. Also, since heavy spreader equipment isn't needed out on the course, equipment costs are lowered drastically. The onetime cost of a fertigation system outweighs the multiple costs of spreading equipment and labour costs heavily. Not having to be out on the course also means that you can apply chemicals in conditions that would make conventional application damaging or impossible.

When fertilizing through fertigation with a well planned and monitored schedule, there is less chance of leachable nutrients not being absorbed by the plant. Usually, the application can be applied with irrigation sche- 
dules so that the liquid fertilizer will only penetrate the first two to three inches of the soil. If timed right, deep percolation at application time is avoided meaning less likelihood of leaching.

The chemistry of fertigation is essential factor in the success of the technique. Its scope covers interaction between fertilizers and irrigation water, behaviour in soil solution and rate of availability to plants, influence on soil structure, the compatibility of commercial fertilizers with application techniques, the composition of nutrient solutions and crop response. Most of the available studies rely on methods to assess the appropriateness of different fertigation strategies [11]. For optimization of fertilizers application, the nutrients supply will be adjusted to the specific requirements of the crop in different phonological stages of growth and development. [12] stated that modern fertigation equipment (Fertilizer injection methods) must be used and should be able to regulate quantity of fertilizer applied, duration of applications, proportion of fertilizes, and starting and finishing time.

[13] recommended that the fertilizer have to be injected at a constant rate during the entire irrigation event. This recommendation assumes that the tail water runoff will be blended with other water and reused in another field. On the other hand, [14] suggested that the fertilizer should be added during the end of the irrigation event to avoid deep penetration of fertilizers to the groundwater. Preliminary studies have indicated that the timing and duration of fertigation applications during the surface irrigation event play a critical role in determining the distribution of fertilizer in the field and the potential movement of nitrate. This is mainly significant in light of evidence that suggests that fertigation may increase rather than decrease leaching of mobile chemicals from crop root zones. [15] conducted a series of fertigation experiments and concluded that the most effective fertigation application practice is expected to be related uniquely to the furrow irrigation method. They added that the infiltration rate of the soil was the most important factor in the choice of injection strategy.

\subsection{Benefits of Fertigation}

Fertigation is a very efficient technique for conserving both water and nitrogen fertilizer and increasing crop production. Because fertigation offers several distinct advantages in comparison to conventional application methods which can be summarized as follow:

- Distribution of plant nutrients more evenly throughout the wetted root zone resulting in increased nutrient availability and uptake contributing to higher crop growth rates and cane yields.

- Application of nutrients to the soil when crop or soil conditions would otherwise prohibit entry into the field with conventional equipment.

- No damage to the crop by root pruning, breakage of leaves, or bending of leaves, as occurs with conventional fertilizer application methods/equipment.

- Less energy is expended in application of the fertilizer.

- Usually less labour and equipment are required for application of the fertilizer and to supervise the application.

\subsection{Objectives of the Study}

The main objective is to develop management practices on the efficient use of water and fertilizers in production of sugar cane, maximize yield, and improve quality. The specific objectives are to:

1. Compare the conventional fertilization (Figure 1) method with fertigation (Figure 2 and Figure 3).

2. Provide recommendations on irrigation scheduling of gated pipe irrigation for optimal water requirements and irrigation production efficiency plus fertilizer use efficiency.

3. Generation of fertilizers formulas (fertigated) for N, P, and K associated with each method of irrigation for optimal yield and efficient fertilizer use efficiency.

4. Build up experiences and new knowledge on advanced technologies of fertigation.

5. Increase the income of sugar cane producer through reducing the input from fertilizers while increasing crop yield.

\section{Materials and Methods}

\subsection{Preface}

In this study urea fertilizer $(46 \% \mathrm{~N})$ is applied as a single dose just before the second irrigation. Normally, the 


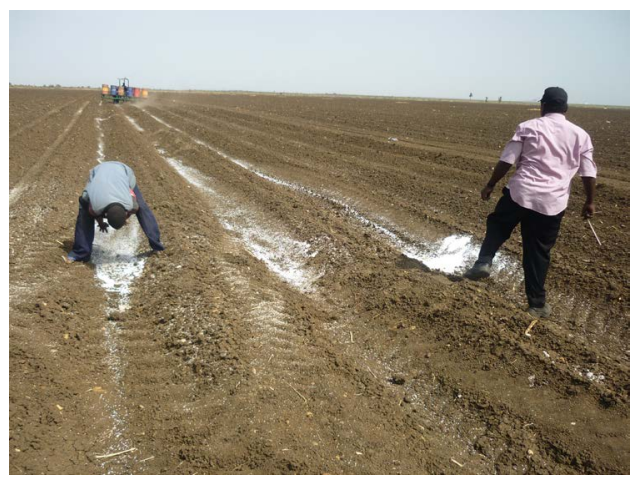

Figure 1. Uneven fertilizer distribution using the conventional fertilization method.

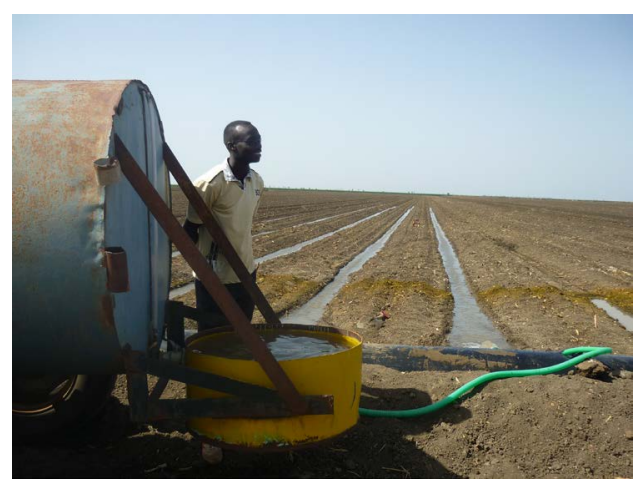

Figure 2. Injection of the dissolved urea fertilizers into the irrigation water by means of 2 inches internal diameters siphon tube.

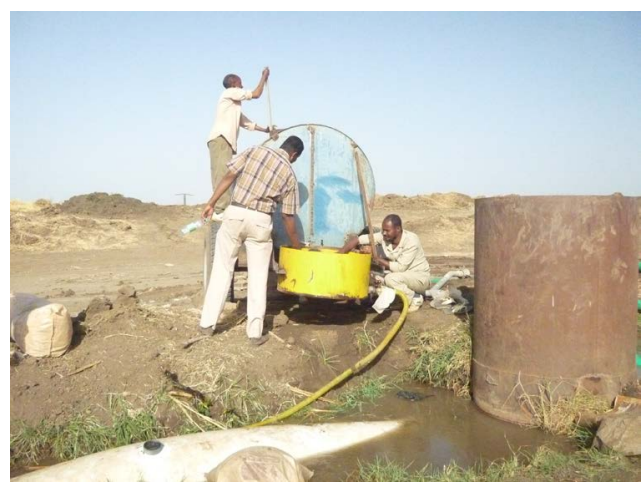

Figure 3. Injection of the dissolved urea fertilizers into the irrigation water by means of pressure differential tank system.

standard practice adopted under Kenana conditions with regard to application of the nitrogen fertilizer in the form of urea $(46 \% \mathrm{~N})$ which is readily soluble in water is that; it is applied at a rate of $92 \mathrm{~kg}$ nitrogen/feddan (200 kg urea/feddan) in the furrows using locally fabricated fertilizer distributor. The applied fertilizer was then incorporated in the soil using rigid tine cultivator.

The present study has considered nitrogen fertilizer in form of urea mainly because it is subject to a greater range of losses than either phosphorous or potassium, and therefore offers more scope for improvements in management. Urea is readily soluble in water and its solubility ratio is 119 grams per 100 grams water at a temperature 25 degrees Celsius. 


\subsection{Site Description}

\subsubsection{Location and Climate}

A fertigation experiment was conducted during 2009/2010 and 2010/2011 seasons under commercial field conditions in Kenana Sugar Scheme, Sudan. Kenana Scheme is located on the eastern bank of the White Nile river, $300 \mathrm{~km}$ south of Khartoum at an altitude of $410 \mathrm{~m}$ above mean sea level (msl), latitude 13.10' $\mathrm{N}$ and longitude of $32.40^{\prime} \mathrm{E}$. The climate of the locality is tropical, dry, hot semi-arid with daily mean maximum temperature of $36.4^{\circ} \mathrm{C}$ and the corresponding mean minimum temperature was $20.2^{\circ} \mathrm{C}$, relative humidity at $08: 00 \mathrm{a} . \mathrm{m}$. was about $47 \%$ (Table 1(a)). The mean annual effective rainfall as shown in Table 1(b) was $278 \mathrm{~mm}$ (for the period 1977 to 2013).

Table 1. (a) Mean monthly reference evapotranspiration (ETo) calculated according to (Penman-Monteith) for the period 1977-2013 in Kenana Scheme*; (b) Mean monthly crop water requirement (CWR) calculated according to (Penman-Monteith) for the period 1977-2013 in Kenana Scheme.

(a)

\begin{tabular}{cccccccc}
\hline Month & $\begin{array}{c}\text { Min. Temp. } \\
\left({ }^{\circ} \mathrm{C}\right)\end{array}$ & $\begin{array}{c}\text { Max Temp } \\
\left({ }^{\circ} \mathrm{C}\right)\end{array}$ & $\begin{array}{c}\text { Relative } \\
\text { humidity } \\
(\%)\end{array}$ & $\begin{array}{c}\text { Wind } \\
\text { speed } \\
(\text { Km/day) }\end{array}$ & $\begin{array}{c}\text { Sunshine } \\
(\mathrm{h})\end{array}$ & $\begin{array}{c}\text { Radiation } \\
{\mathrm{M} \cdot \mathrm{Jm}^{-2}}^{-}\end{array}$ & $\begin{array}{c}\text { ETo Penman- } \\
\text { Monteith } \\
(\mathrm{mm} / \text { day })\end{array}$ \\
\hline Jan & 12.6 & 31.3 & 38 & 170 & 10.2 & 21.3 & 5.6 \\
Feb. & 17.1 & 36 & 35 & 153 & 9.5 & 22 & 6.3 \\
March & 18.7 & 38.6 & 25 & 139 & 9.8 & 24.1 & 7.2 \\
April & 21.2 & 41.4 & 18 & 148 & 10.7 & 26.1 & 7.2 \\
May & 23.2 & 41.3 & 27 & 114 & 10.2 & 25 & 6.7 \\
June & 24 & 37 & 56 & 225 & 9.1 & 22.9 & 6.3 \\
July & 23.4 & 36.2 & 69 & 132 & 7.5 & 20.7 & 4.6 \\
Aug. & 21.7 & 31.7 & 81 & 225 & 5.8 & 18.3 & 4.2 \\
Sept. & 21.8 & 34.1 & 73 & 225 & 7.8 & 20.1 & 4.6 \\
Oct. & 21.6 & 37.8 & 58 & 180 & 10 & 23 & 4.9 \\
Nov. & 19.6 & 35.8 & 38 & 118 & 10.5 & 22 & 5.4 \\
Dec & 17.1 & 35.4 & 40 & 163 & 10.3 & 20.8 & 5.1 \\
Mean & 20.2 & 36.4 & 46.5 & 166 & 9.3 & 22.2 & 5.7 \\
\hline
\end{tabular}

* Data taken from monthly weather reports of Sugarcane Research Meteorological Station at Kenana.

(b)

\begin{tabular}{cccccccc}
\hline Month & $\begin{array}{c}\text { Eenman-Monteith } \\
(\mathrm{mm} / \text { day })\end{array}$ & Kc-value & $\begin{array}{c}\text { CWR } \\
(\mathrm{mm} / \text { day })\end{array}$ & $\begin{array}{c}\text { Days of the } \\
\text { month }\end{array}$ & $\begin{array}{c}\text { CWR } \\
(\mathrm{mm} / \text { month) }\end{array}$ & $\begin{array}{c}\text { Effective rainfall } \\
\text { (mm/month) }\end{array}$ & $\begin{array}{c}\text { CWR } \\
\text { (mm/month) }\end{array}$ \\
\hline Jan & 5.6 & 0.6 & 3.36 & 31 & 104 & 0.0 & 104 \\
Feb & 6.3 & 0.7 & 4.41 & 28 & 123 & 0.0 & 123 \\
March & 7.2 & 0.8 & 5.4 & 31 & 167 & 0.0 & 167 \\
April & 7.2 & 0.8 & 5.76 & 30 & 173 & 0.0 & 173 \\
May & 6.7 & 1.1 & 7.37 & 31 & 228 & 21.0 & 207 \\
June & 6.3 & 1.3 & 8.19 & 30 & 246 & 55.0 & 191 \\
July & 4.6 & 1.2 & 5.52 & 31 & 171 & 52.7 & 118 \\
Aug & 4.2 & 1.0 & 4.2 & 31 & 130 & 90.6 & 40 \\
Sept & 4.6 & 1.0 & 4.6 & 30 & 138 & 46.2 & 92 \\
Oct & 4.9 & 1.0 & 4.9 & 31 & 152 & 12.5 & 139 \\
Nov & 5.4 & 1.0 & 5.4 & 30 & 162 & 0.0 & 162 \\
Dec & 5.1 & 0.9 & 4.59 & 31 & 142 & 0.0 & 142 \\
Total & 68.1 & 11.4 & 63.7 & 365 & 1938 & 278.0 & 1660 \\
Mean & 5.7 & 0.9 & 5.3 & 30.4 & 161 & 23.2 & 138 \\
\hline
\end{tabular}




\subsubsection{The Soil}

The soil of the area is heavy montmorillonitic clay, brown in colour, uniform and alkaline in reaction ( $\mathrm{pH}$ ranged between 7.5 and 8.5). It is non-saline non-sodic containing about $65 \%$ clay, $24 \%$ silt and $11 \%$ sand, with very low infiltration rate $\left(300 \mathrm{~cm}^{3} \cdot \mathrm{m}^{-1} \cdot \mathrm{hr}^{-1}\right)$. The mean values of the soil physicochemical parameters are presented in Table 2(a) and Table 2(b).

\subsubsection{Treatments}

In both seasons four treatments were studied in a randomized complete block design with three replications as; Injection of the dissolved urea $(46 \% \mathrm{~N})$ during entire irrigation time (100\%). during the first half of the irrigation time, during the second half of the irrigation time, and Mechanical application of urea using fertilizer distributor and rigid Tyne cultivator. The first three treatments were applied with the third irrigation cycle through the irrigation water.

In the present study the sugarcane cultivar (Co 6806) was planted in plots each containing 20 rows, $650 \mathrm{~m}$. long and $1.5 \mathrm{~m}$ between ridges in a randomized complete block design with three replications. The cultivar Co 6806 which was originated in Coimbatore districts of India is considered as high quality cultivar, it performs well in all types of soil. The cultivar Co 6806 is considered as the most popular and leading commercial cultivar. Among the profitable cultivars grown, Co 6806 is now expanded over $80 \%$ of the area devoted for sugarcane plantation at the Sudanese sugar estates. It was introduced during the late seventies. In virtue of its high genetic capacity to produce high yields of cane and sugar besides its ability to resist endemic pests and diseases namely smut, it remained to be as number one across sugar estates and represents a major fruitful achievement of the sugarcane introduction strategy during the late seventies.

The cultivar Co 6806 is classified as an early season cultivar, with medium size, green in colour (Figure 4). Generally the colour of the leaf sheath is green with pink tinge and dark green spines. The mean cane and sugar yields of the cultivar Co 6806 when harvested at the age of 12 months is about 120 ton cane/hectare and 14 ton sugar/hectare, respectively.

The application dose of urea practised under Kenana conditions and also used in the present study was $200 \mathrm{~kg}$ of urea/feddan (92 kg nitrogen). Phosphorus at a rate of $50 \mathrm{Kg}$ TSP was added identically to all treatments. Potassium was not applied to any due to high soil $\mathrm{K}$ content.

During the process of fertigation technique the irrigation water from the gated pipe was applied to the field from the riser (Field Outlet Pipe) and the dissolved urea was supplied at the site and controlled with a valve

Table 2. (a) Physical properties of Kenana soils; (b) Chemical properties of Kenana soils.

(a)

\begin{tabular}{|c|c|c|c|c|c|c|c|}
\hline \multirow{2}{*}{$\begin{array}{l}\text { Soil depth } \\
\text { (cm) }\end{array}$} & \multicolumn{3}{|c|}{ Mechanical analysis } & \multirow[t]{2}{*}{ Field capacity } & \multirow[t]{2}{*}{ Saturation } & \multirow[t]{2}{*}{ Permanent wilting point } & \multirow{2}{*}{$\begin{array}{l}\text { Bulk density } \\
\left(\text { gram } / \mathrm{cm}^{3} \text { ) }\right.\end{array}$} \\
\hline & Sand & Silt & Clay & & & & \\
\hline \multicolumn{8}{|c|}{$\%$} \\
\hline $0-20$ & 11 & 24 & 65 & 46 & 70 & 20 & 1.16 \\
\hline $20-40$ & 10 & 22 & 68 & 44 & 66 & 18 & 1.25 \\
\hline $40-60$ & 09 & 22 & 69 & 41 & 67 & 21 & 1.23 \\
\hline $60-80$ & 09 & 20 & 71 & 42 & 69 & 19 & 1.29 \\
\hline
\end{tabular}

(b)

\begin{tabular}{|c|c|c|c|c|c|c|c|c|}
\hline \multirow{3}{*}{$\begin{array}{l}\text { Soil depth } \\
\quad \text { (cm) }\end{array}$} & \multirow{2}{*}{$\begin{array}{c}\text { Soil PH } \\
\text { Soil:water }\end{array}$} & \multirow{2}{*}{ E.Ce } & \multirow{2}{*}{$\mathrm{CaCO}_{3}$} & \multirow{2}{*}{$\mathrm{N}$} & \multirow{2}{*}{ O.C. } & \multicolumn{3}{|c|}{ Soluble cations } \\
\hline & & & & & & $\mathrm{Na}$ & $\mathrm{Ca}$ & $\mathrm{Mg}$ \\
\hline & $1: 5$ & $\mathrm{Dsm}^{-1}$ & & (\%) & & \multicolumn{3}{|c|}{ Milli-equivalent/liter } \\
\hline $0-20$ & 7.6 & 0.45 & 0.5 & 0.051 & 0.82 & 0.2 & 1.9 & 0.2 \\
\hline $20-40$ & 7.8 & 0.35 & 1.2 & 0.055 & 0.61 & 0.7 & 1.6 & 0.9 \\
\hline $40-60$ & 8.1 & 0.33 & 2.2 & 0.070 & 0.50 & 1.2 & 1.4 & 0.6 \\
\hline $60-80$ & 8.2 & 0.50 & 1.9 & 0.024 & 0.47 & 2.0 & 1.1 & 0.3 \\
\hline
\end{tabular}




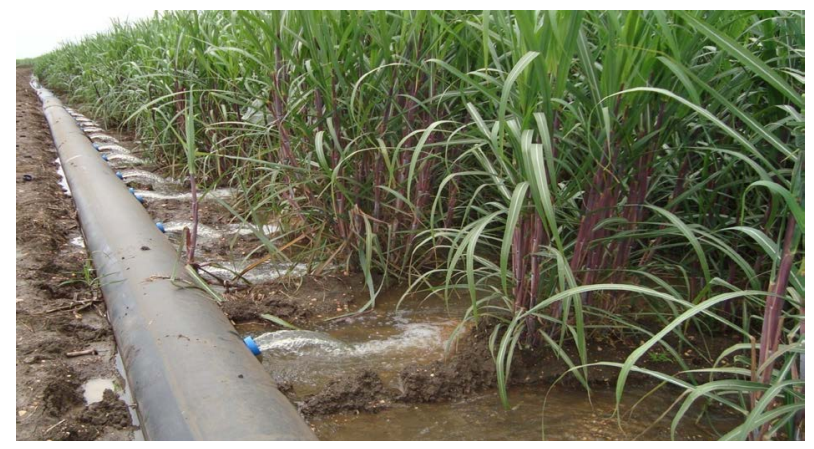

Figure 4. General features of cultivar Co 6806.

connected to the fertilizer tank using water pump and fertilizer agitator. The timing and the amount of water applied and the dissolved urea together with the inflow rates were calculated and recorded every minute for each treatment as presented in Table 3(a) and Table 3(b) (Figure 2 and Figure 3). Storage tank of 4000 litter capacity (with agitator and water pump) for dissolving and injection of the fertilizer into riser of the gated pipes were designed and calibrated to control the dose of fertilizer input per each treatment and the irrigation water supplied to furrows. The fertilizers were injected into the irrigation water by means of pressure differential tank system which is based on the principle of a pressure differential being created by a valve and flow regulator forcing and injecting a varying amount of dissolved fertilizer into the irrigation water (Figure 2 and Figure 3).

Weed control in the present trials was achieved mainly through the application of a mixture of one kilogram Gesapax (Ametryne) and one kilogram Gesaprim (Atrazine) just before the second irrigation and another follow-up treatment as band application of the same chemicals and dose after hilling-up (3.5 - 4 months from planting). Between the two herbicide applications, weeding before hilling- up operation was achieved by a dual purpose implement (weeder-reshaper) which control weeds and reshapes the ridges.

Satisfactory and economical control of Termite damage was achieved by the use of chlorinated hydrocarbon insecticides. This is because of the long lasting residual protection afforded by these insecticides to the sets. "Dursban 48EC" insecticide at the dosage rate of 1.0 litter product per feddan was also applied for the control of termites. Various cultural practices now in use at Kenana have appreciably decreased termites inflicted on sugarcane.

\subsubsection{Experiment Procedures and Measurements}

In the present study the reference evapotranspiration (ETo) for Kenana estate was computed (Table 1(a)) using the FAO-Penman-Monteith method and the CROPWAT software. CROPWAT was for calculating the reference evapotranspiration (ETc in mm·day ${ }^{-1}$ ) for each month of the growing season upon entry of the required meteorological data (Monthly mean minimum and maximum temperature, relative humidity, wind speed, sunshine hours and solar radiation). Sugarcane crop coefficients $(\mathrm{kc})$ for different growth stages were determined following the procedure described by [16]. Then the amounts of water required for the plant was determined as a function of the local climatic data (Table 1(b)).

Soil samples were taken before starting the experiment and just after harvesting the sugarcane crop from the soil depths of 0 - 15; 15 - 30; and 30 - $60 \mathrm{~cm}$ at furrow top, middle and the bottom third. The collected soil samples were then analyzed for nitrogen concentration after extracted with water using 10 gram of soil and $10 \mathrm{~mL}$ of water and the results were recorded in Table 4. During the growing season plant leaf samples were taken from each treatment at the age of six month for the determination of nitrogen concentration (Table 5). The cane was harvested at the age of 12 months and the following growth and yield parameters were determined:

(i) The stem height, $(\mathrm{cm})$ from the soil surface to the top most visible dewlap was recorded in a random sample of 10 plants following the procedure described by [17].

(ii) The stem diameter, $(\mathrm{cm})$ was measured at harvest time using vernier calliper at $30 \mathrm{~cm}$ above the soil surface.

(iii) Cane yield and yield components were determined after harvesting the crop and the data obtained were presented in Table 7(a) and Table 7(b).

Finally, the data obtained from the present study were subjected to the analysis of variance using [18]. The 
Table 3. (a) Rates of inflow of irrigation water and dissolved urea used in the process of fertigation technique (first season 2009/2010); (b) Rates of outflow of irrigation water and dissolved urea used in the process of fertigation (second season 2010/2011).

(a)

\begin{tabular}{lcccc}
\hline Treatment & $\begin{array}{c}\text { Total irrigation time } \\
\text { (hour) }\end{array}$ & $\begin{array}{c}\text { Inflow rate } \\
\text { of irrigation } \\
\text { water/outlet (L/s) }\end{array}$ & $\begin{array}{c}\text { Injection } \\
\text { Time (hour) }\end{array}$ & $\begin{array}{c}\text { Total inflow rate } \\
\text { of the dissolved } \\
\text { urea/20 outlets (L/s) }\end{array}$ \\
\hline $\begin{array}{l}\text { Continuous injection of the dissolved urea } \\
\begin{array}{l}\text { Injection of the urea during the first half of } \\
\text { irrigation time }\end{array}\end{array}$ & 6 & 2.6 & 6 & 7.4 \\
$\begin{array}{l}\text { Injection of the urea during the second half of } \\
\text { irrigation time. }\end{array}$ & 6 & 2.6 & 3 & 3 \\
Mechanical application of urea & 6 & 2.6 & 6 & 14.8 \\
Mean & 6 & 2.6 & 4.5 & - \\
\hline
\end{tabular}

(b)

\begin{tabular}{|c|c|c|c|c|}
\hline Treatments & $\begin{array}{l}\text { Total irrigation time } \\
\text { (hour) }\end{array}$ & $\begin{array}{c}\text { Flow rate } \\
\text { of irrigation } \\
\text { water/outlet }(\mathrm{L} / \mathrm{s})\end{array}$ & $\begin{array}{l}\text { Injection } \\
\text { Time (hour) }\end{array}$ & $\begin{array}{l}\text { Flow rate of } \\
\text { the dissolved urea } \\
(\mathrm{L} / \mathrm{s})\end{array}$ \\
\hline Continuous injection of the dissolved urea & 8 & 2.2 & 8 & 0.25 \\
\hline $\begin{array}{l}\text { Injection of the urea during the first half of } \\
\text { irrigation time }\end{array}$ & 8 & 2.2 & 4 & 0.25 \\
\hline $\begin{array}{l}\text { Injection of the urea during the second half of } \\
\text { irrigation time. }\end{array}$ & 8 & 2.2 & 4 & 0.25 \\
\hline Mechanical application of urea & 8 & 2.2 & - & 4 bags/acre \\
\hline Mean & 8 & 2.2 & 6 & - \\
\hline
\end{tabular}

Table 4. Average values of the soil nitrogen content for the different treatments.

\begin{tabular}{|c|c|c|c|c|}
\hline \multirow[b]{2}{*}{ Treatments } & \multirow{2}{*}{$\begin{array}{l}\text { Number of composite } \\
\text { samples }\end{array}$} & \multirow[b]{2}{*}{ Soil depth } & \multicolumn{2}{|c|}{ Soil nitrogen content ( \% ) } \\
\hline & & & $\begin{array}{l}\text { Crop season } \\
2009 / 2010\end{array}$ & $\begin{array}{c}\text { Crop season } \\
2009 / 2010\end{array}$ \\
\hline Continuous injection of the dissolved urea & 18 & $0-60 \mathrm{~cm}$ & 0.43 & 0.43 \\
\hline $\begin{array}{l}\text { Injection of the urea during the first half of } \\
\text { irrigation time }\end{array}$ & 18 & $0-60 \mathrm{~cm}$ & 0.27 & 0.32 \\
\hline $\begin{array}{l}\text { Injection of the urea during the second half of } \\
\text { irrigation time. }\end{array}$ & 18 & $0-60 \mathrm{~cm}$ & 0.18 & 0.20 \\
\hline Mechanical application of urea & 18 & $0-60 \mathrm{~cm}$ & 0.14 & 0.11 \\
\hline Mean & & & 0.25 & 0.26 \\
\hline $\mathrm{CV} \%$ & & & 13 & 15 \\
\hline $\mathrm{SE}+$ & & & 0.18 & 0.04 \\
\hline
\end{tabular}

Table 5. Average values of the leaf nitrogen content for the different treatments.

\begin{tabular}{|c|c|c|c|c|}
\hline \multirow[b]{2}{*}{ Treatments } & \multirow[b]{2}{*}{ Number of samples } & \multirow[b]{2}{*}{ Cane age (month) } & \multicolumn{2}{|c|}{ Leaf nitrogen content ( \% ) } \\
\hline & & & $\begin{array}{c}\text { Crop season } \\
2009 / 2010\end{array}$ & $\begin{array}{c}\text { Crop season } \\
2009 / 2010\end{array}$ \\
\hline Continuous injection of the dissolved urea & 9 & 6 & 2.8 & 2.7 \\
\hline $\begin{array}{l}\text { Injection of the urea during the first half of } \\
\text { irrigation time }\end{array}$ & 9 & 6 & 2.4 & 2.4 \\
\hline $\begin{array}{l}\text { Injection of the urea during the second half of } \\
\text { irrigation time. }\end{array}$ & 9 & 6 & 2.2 & 2.0 \\
\hline Mechanical application of urea & 9 & 6 & 1.5 & 1.7 \\
\hline Mean & & & 2.2 & 2.2 \\
\hline $\mathrm{CV} \%$ & & & 14 & 16.7 \\
\hline $\mathrm{SE}+$ & & & 0.16 & 0.15 \\
\hline
\end{tabular}


Duncan Multiple Range Test (DMRT) was used to compare the means [19].

\section{Results and Discussions}

In the present study the seasonal amount of water requirements for sugarcane crop were determined as a function of the local climatic data (Table 1(b)). The average values of the irrigation water required to satisfy the sugarcane needs based on the available information on evapotranspiration of the crop were calculated. The accurate determinations of the irrigation water required per each treatment are helpful in managing the dose of fertilizer input per each treatment and the irrigation water supplied to furrows. Accordingly, the injection rates of the dissolved urea in relation to the rate of flow of irrigation water will be defined and monitored by an injector valve. Because when fertilizing through fertigation with a well planned and monitored irrigation schedule, there is less chance of leachable nutrients not being absorbed by the plant. Then the amounts of water required for the plant.

\subsection{Soil Nitrogen Distribution}

The results of the average values of nitrogen concentrations of the soil samples collected and analyzed before starting the fertigation experiment indicated that the average initial soil nitrogen concentrations is about $0.06 \%$ with a range of 0.04 to $0.08 \%$, which is considered as very low according to the broad rating of nitrogen percent in soils (Table 6(a)) as given by [20].

Also the results of soil samples taken just after harvesting the sugarcane crop from the soil depths of 0 - 15; 15 - 30; and 30 - $60 \mathrm{~cm}$ at furrow top, middle and the bottom third were recorded and presented in Table 3. The collected soil samples were then analyzed for nitrogen concentration after extracted with water using 10 gram of soil and $10 \mathrm{~mL}$ of water and the results were recorded in Table 4. In both seasons the obtained results revealed that, following fertigation, the nitrogen concentration along the length of run was highest in the top $15 \mathrm{~cm}$ of soil for most treatments and decrease with depth. The present study also indicated that when the dissolved urea (46\% N) was injected during the entire irrigation time (100\% treatment), soil nitrogen concentrations for each soil depth in the furrow (top, middle and bottom third) were similar along the entire length of the field. Whereas, when the dissolved urea injected during the first half of the irrigation, nitrogen concentrations in the soil were higher at the lower end of the field than at the upper end. Greater total nitrogen at the lower end than at the upper end occurred because of the longer infiltration opportunity time of nitrogen-amended water at the lower end. Soil nitrogen concentrations along the furrows where nitrogen injection was made during the last half of the irrigation were higher at the head end of the field, with almost no nitrogen at the lower end of the field. This is due to the early rapid infiltration of un-amended water in the furrows at the upper end of the field. Injection during the last half of the irrigation resulted in little total nitrogen at the tail end of the field and the largest accumulation of total nitrogen at the head end of the field. [21] using similar treatments for level furrows, found similar results and concluded that injection of nitrogen concentrations during the entire irrigation time of level

Table 6. (a) Explains the broad rating of nitrogen percent in soils as given by (Landon, 2014)*; (b) The rating of sugarcane leaf total nitrogen percent as given by the Agricultural Extension of Florida, USA.

(a)

\begin{tabular}{cc}
\hline Nitrogen content (\%), Kjeldahl Method & Rating \\
\hline 1.0 & very high \\
$0.5-1.0$ & high \\
$0.2-0.5$ & medium \\
$0.1-0.2$ & low \\
$<0.1$ & very low \\
\hline
\end{tabular}

Landon adapted from Metson 1961.

(b)

\begin{tabular}{ccc}
\hline Country & Reference & Optimum leaf nitrogen percent \\
\hline USA & (McCray \& Mylavarapu, 2010) & $2.0-2.6$ \\
\hline
\end{tabular}


Table 7. (a) Yield and yield components obtained during crop season 2009/2010 (first season); (b) Yield and yield components obtained during crop season 2010/2011 (second season).

(a)

\begin{tabular}{lccc}
\hline Treatment & Plant height $(\mathrm{cm})$ & Plant diameter $(\mathrm{cm})$ & Cane yield (TCF) \\
\hline Continuous injection of the dissolved urea & 298 & 2.5 & 45.0 \\
Injection of the urea during the first half of irrigation time & 282 & 2.3 & 43.4 \\
Injection of the urea during the second half of irrigation time. & 275 & 2.0 & 42.0 \\
Mechanical application of urea & 255 & 1.9 & 36.4 \\
Mean & 278 & 1.6 & 40.9 \\
CV\% & 2.36 & 10.23 & 6.67 \\
SE+ & 2.67 & 0.13 & 1.12
\end{tabular}

(b)

\begin{tabular}{lccc}
\hline Treatment & Plant height $(\mathrm{cm})$ & Plant diameter $(\mathrm{cm})$ & Cane yield (TCF) \\
\hline Continuous injection of the dissolved urea & 305 & 2.6 & 41.0 \\
Injection of the urea during the first half of irrigation time & 292 & 2.1 & 38.4 \\
Injection of the urea during the second half of irrigation time. & 282 & 1.5 & 34.0 \\
Mechanical application of urea; & 275 & 1.5 & 32.9 \\
Mean & 289 & 1.9 & 36.6 \\
CV\% & 13 & 0.16 & 6.74 \\
SE+ & 4.75 & 1.06
\end{tabular}

furrows also produced the highest uniformity for nitrogen concentrations, but that injection during the first half of the irrigation time was the next best option. [22] also found that injection during last half of the irrigation produced significantly lower uniformity than injection during the entire irrigation or first half.

With respect to the mechanical application of urea using fertilizer distributor and rigid Tyne cultivator (conventional method), fertiliser was first broadcasted and then incorporated in the furrows. Due to root pruning, fertiliser incorporated in the furrows, away from the sides of the ridges, would not be easily accessible to the roots of the ratoon cane. Additionally, it was observed that the rigid Tyne cultivator did not completely cover the broadcasted fertilisers (Figure 4) and that would eventually lead to loss of urea through volatilization. Moreover, it was also observed that during broadcasting, fertiliser was sometimes drifted to the top of cane rows, where they could not be incorporated and thus provided an additional source for losing urea to the atmosphere. Accordingly, very poor nitrogen use efficiency was obtained that resulted in lower yield and yield components (Table 7(a) and Table 7(b)). [23] revealed that adoption of proper method of fertiliser application is essential to minimize nutrient losses from the soil and for increasing fertiliser use efficiency. According to [24] fertilisers should be placed close to the root zone to enable the roots to derive its benefit immediately. Beside increasing cane yield, proper placement also reduces volatilization losses of nitrogenous fertilisers. [25] mentioned that when applied to the soil, urea [CO(NH$)_{2}$ ] is converted to ammonia $\left(\mathrm{NH}_{3}\right)$ by an enzyme called urease, then to ammonium $\left(\mathrm{NH}_{4}\right)$. If that reaction occurs at the soil surface, some of the nitrogen will be lost to the atmosphere. However, if it occurs in soil the ammonia will convert to ammonium and will be held by the clay particles.

\subsection{Leaf Nitrogen Distribution}

Results of the present study indicated that improvement in leaf nitrogen due to continuous injection of urea were better in both seasons and significantly $(\mathrm{P}<0.05)$ increase yield and yield components due to that continuous injection of nitrogen fertilizer satisfy the nitrogen demand of sugarcane crop leading to better uptake of the dissolved nitrogen fertilizer than the other treatments (Table 5), whereas the mechanical application approach 
leading to the worst nitrogen uptake.

In both seasons the results of plant leaf analysis data were then compared with the international references mainly, the rating of sugarcane leaf total nitrogen percent as given by the Agricultural Extension of Florida, USA (Table 6(b)).

\subsection{Stem Height and Diameter (cm)}

Data on the effect of different fertigation strategies on stem height are given in Table 6(a) and Table 6(b). In both seasons the results show that, continuous injection of urea significantly $(\mathrm{P}<0.05)$ increase stalk height as compared to the other diameter (Table 7(a) and Table 7(b)) showed that the different treatments had no significant effect on stem diameter in both seasons. The insignificant reduction in stem diameter associated with mechanical application of urea (in both seasons) may be due to the fact that the crop was grown under deficit nitrogen conditions that restricted stem thickness. These parameters were believed to be the first to be affected by nitrogen stress on treatments. However, mechanical urea application produced the poorest stalk height, because the crop nitrogen requirement was not satisfied. The effect of different fertigation strategies on stem the other hand, the highest values of stem diameter occurred in plants fertigated at $100 \%$ irrigation time.

\subsection{Cane Yield}

Cane yield and yield components were determined after harvesting the crop and the data obtained were presented in Table 7(a) and Table 7(b). Results obtained indicated that in both seasons continuous injection of the dissolved urea $(46 \% \mathrm{~N})$ during the entire irrigation time $(100 \%)$, significantly $(\mathrm{P}<0.05)$ increased the average cane yield (ton/feddan), whereas the lowest cane yield was recorded when urea was applied mechanically. The increase in cane yield and yield components with the continuous injection of the dissolved urea as compared to the other treatments could be because of a more uniform water distribution during the whole irrigation time resulting in an improved distribution of the fertilizer.

\section{Conclusions}

Following the evidence presented in this paper, the following conclusions are proposed:

When the dissolved urea was injected during the entire irrigation time, soil nitrogen concentrations for each soil depth in the furrow (top, middle and bottom third) were similar along the entire length of the field. Nevertheless, when the dissolved urea was injected during the first half of the irrigation, nitrogen concentrations in the soil were higher at the lower end of the field than at the upper end because of the longer infiltration opportunity time of nitrogen-amended water at the lower end. Soil nitrogen concentrations along the furrows where nitrogen injection was made during the last half of the irrigation were higher at the head end of the field, with almost no nitrogen at the lower end of the field. This is due to the early rapid infiltration of un-amended water in the furrows at the upper end of the field. Injection during the last half of the irrigation resulted in little total nitrogen at the tail end of the field and the largest accumulation of total nitrogen at the head end of the field.

Also it is concluded that continuous injection of the dissolved urea during the entire irrigation time produced the best distribution uniformity of added nitrogen and increase in the plant height, diameter and cane yield, whereas injection of the dissolved urea during the first half of the irrigation time was the next. However, these differences were only significant when comparing the mechanical application of urea with fertigation treatments. It worth emphasizing that the differences were not significant between the three fertigation treatments. Additional field studies are needed with different operational conditions to develop more complete guidelines for fertigation using gated-pipe furrow irrigation system.

\section{Recommendations}

Based on two season's results the author recommends that, regulation of the injection of fertilizer to match the flow of irrigation water is so precise that application rates are substantially lowered. Accordingly, fertilization of the sugarcane crop (ratoons) should be carried out via fertigation strategy mainly through injection of the dissolved urea $(46 \% \mathrm{~N})$ during the entire irrigation time $(100 \%$ treatment). Because this treatment produced the best distribution uniformity of added nitrogen compared to the injection during the first or the second half of the 
Table 8. Benefits gained and cost saved due to introduction of fertigation.

\begin{tabular}{|c|c|c|}
\hline Parameter & Fertigation technique & Conventional fertilizer application method \\
\hline $\begin{array}{l}\text { Uniformity of fertilizer } \\
\text { application }\end{array}$ & $\begin{array}{l}\text { Distribute the dissolved urea more evenly } \\
\text { throughout the wetted root zone, with less } \\
\text { labour }\end{array}$ & $\begin{array}{l}\text { Intensive, time consuming and do not provide proper } \\
\text { fertilizer placement on ratoon fields. }\end{array}$ \\
\hline Area fertilized per day & Depend on the area to be irrigated/day & Using fertilizer applicator, only 100 feddan/10 hours a day. \\
\hline $\begin{array}{l}\text { Tractor horsepower required } \\
\text { for application of the fertilizer. }\end{array}$ & $\begin{array}{l}\text { Lowest fuel consumption and energy were } \\
\text { required only to transport the fertilizer storage } \\
\text { tank once. } \\
\text { Fertigation leads to saving of tractor } \\
\text { horse-power and operation cost and time. }\end{array}$ & $\begin{array}{l}\text { Broadcasting of fertilizers in separate operations represented } \\
\text { an inefficient use of tractor power and time. } \\
\text { The broadcasters required only partial power to operate the } \\
\text { metering mechanism }(0.05 \mathrm{~kW}) \text {. The weight of filled } \\
\text { fertiliser hoppers added } 1.68 \mathrm{~kW} \text { to the rolling resistance of } \\
\text { the tractor. Maximum power for a broadcaster was therefore } \\
\text { around } 1.73 \mathrm{~kW} \text {. This almost means that the power of the } \\
\text { tractor was only utilized to transport itself across the field. }\end{array}$ \\
\hline $\begin{array}{l}\text { Incorporation and covering } \\
\text { of the applied fertilizer }\end{array}$ & $\begin{array}{l}\text { This operation is not required accordingly, } \\
\text { more energy and power were saved. }\end{array}$ & $\begin{array}{l}\text { The average output/10 hours a day when using the rigid } \\
\text { Tyne cultivator is about } 30 \text { feddan. This operation required } \\
\text { about } 12.32(\mathrm{~kW}-\mathrm{h}) / \mathrm{ha}\end{array}$ \\
\hline
\end{tabular}

irrigation time. Also fertigation leads to elimination and saving of tractor horse-power and operation cost and time (Table 8).

\section{References}

[1] Moberly, P. and Meyer, J.H. (1984) Soils: A Management Factor in Sugarcane Production in the South African Sugar Industry. Proceedings of the South African Sugar Technologist's Association, 58, 192-197.

[2] Bakker, M. (1999) Sugarcane Cultivation and Management. Kluwer Academic/Plenum Publishers, New York. http://dx.doi.org/10.1007/978-1-4615-4725-9

[3] Meyer, J.H. and Wood, A.W. (2000) Soil Management Research for Sustainable Cane Production in the 21st Century. In: Wilson, J.R., Hogarth, D.M., Campbell, J.A. and Garside, A.L., Eds., Sugarcane: Research towards Efficient and Sustainable Production. CSIRO, Brisbane, 343-358.

[4] Papadopoulos, I. (1996) Micro-Irrigation Systems and Fertigation. In: Pereira, L.S., et al., Eds., NATO ARW on Sustainability of Irrigated Agriculture, Kluwer Academia Publishers, New York, 309-322.

[5] Brady, N. and Weil, R. (1999) The Nature and Properties of Soils. Prentice Hall, Upper Saddle River.

[6] Plaster, E. J. (2003) Soil Science and Management. 4th Edition, Delmar Learning, USA.

[7] Burt, C., O’Connor, K. and Ruehr, T. (1995) Fertigation. California Polytechnic State University, Irrigation Training and Research Center, San Luis Obispo.

[8] Beth, F. and Filters, A. (1981) Fertigation Gains Increasing Acceptance. Irrigation Farmer, 8, 2.

[9] Howell, T.A., Stevenson, D.S., Aljibury, F.K., Gitlin, H.M., Wu, I.P., Warrick, A.W. and Raats, P.A.C. (1980) Design and Operation of Trickle (Drip) Systems. In: Jensen, M. E., Ed., Design and Operation of Farm Irrigation Systems, ASAE, St. Joseph, 663-717.

[10] Playán, E. and Faci, J.M. (1997) Border Fertigation: Field Experiments and a Simple Model. Irrigation Science, 17, 163-171. http://dx.doi.org/10.1007/s002710050035

[11] Boldt, A.L., Watts, D.G., Eisenhauer, D.E. and Schepers, J.S. (1994) Simulation of Water-Applied Nitrogen Distribution under Surge Irrigation. Transactions of the ASABE, 37, 1157-1165. http://dx.doi.org/10.13031/2013.28189

[12] Garside, A.L. and Nable, R.O. (1996) Sugarcane Growth and Yield Comparisons in Paired Old and New Land Sites. In: Wilson, J.R., Hogarth, D.M., Campbell, J. and Garside, A.L., Eds., Sugarcane: Research towards Efficient and Sustainable Production, CSIRO Division of Tropical Crops and Pastures, Brisbane, 248-250.

[13] Burt, C.M. (1995) Irrigation Evaluations. In: The Surface Irrigation Manual, Waterman Industries, Inc., Exeter, 14.1-14.21.

[14] Bouwer, H. (1990) Agricultural Chemicals and Groundwater Quality. Journal of Soil and Water Conservation, 45, 184-189.

[15] Watts, D.G., Ostermeier, K.A., Eisenhauer, D.E. and Schepers, J.S. (1993) Fertigation by Surge Irrigation on BlockedEnd Furrows. Proceedings of Conference on Agricultural Research to Protect Water Quality, Minneapolis, 21-24 February 1993, 523-526.

[16] Farbrother, H.G. (1971) Crop Water Requirements (CWR) of Sugarcane and Net Irrigation Requirement in the North West Sennar Area. Agronomy and Crop Physiology Section. Gezira Research Station. 
[17] Clements, H.F. (1980) Sugarcane Crop Logging and Crop Control: Principles and Practices. University Press of Hawaii, Honolulu.

[18] SAS Institute (1990) SAS/STAT User’s Guide 1990 Edition. SAS Institute, Inc., Cary.

[19] Gomez, K.A. and Gomez, A.A. (1984) Statistical Procedures for Agricultural Research. 2nd Edition, John Wiley and Sons Inc., New York.

[20] Landon, J.R. (2014) Booker Tropical Soil Manual: A Handbook for Soil Survey and Agricultural Land Evaluation in the Tropics and Subtropics. In: 2000 Symposium: Sugarcane: Research towards Efficient and Sustainable Production, Routledge, London, 237-240.

[21] Abbasi, F., Simunek, J., van Genuchten, M.T., Feyen, J., Adamsen, F.J., Hunsaker, D.J., Strelkoff, T.S. and Shouse, P. (2003) Overland Water Flow and Solute Transport: Model Development and Field-Data Analysis. Journal of Irrigation and Drainage Engineering, 129, 71-81. http://dx.doi.org/10.1061/(ASCE)0733-9437(2003)129:2(71)

[22] Adamsen, F.J. and Rice, R.C. (1995) Nitrate and Water Transport as Affected by Fertilizer and Irrigation Management. Proceedings of 21st Century Conference: Clean Water-Clean Environment: Vol. II. Nutrients, 1-4.

[23] Watts, D.G. and Schepers, J.S. (1995) Fertigation to Reduce Nitrate Contamination of Groundwater. Proceedings of 21st Century Conference: Clean Water-Clean Environment: Vol. II. Nutrients, 239-242.

[24] Verma, R.S. (2002) Sugarcane Ratoon Management. International Distribution Company, India.

[25] Deer and Company (1993) Soil Management. Deer and Company Service Publications, Moline. 
Scientific Research Publishing (SCIRP) is one of the largest Open Access journal publishers. It is currently publishing more than 200 open access, online, peer-reviewed journals covering a wide range of academic disciplines. SCIRP serves the worldwide academic communities and contributes to the progress and application of science with its publication.

Other selected journals from SCIRP are listed as below. Submit your manuscript to us via either submit@scirp.org or Online Submission Portal.
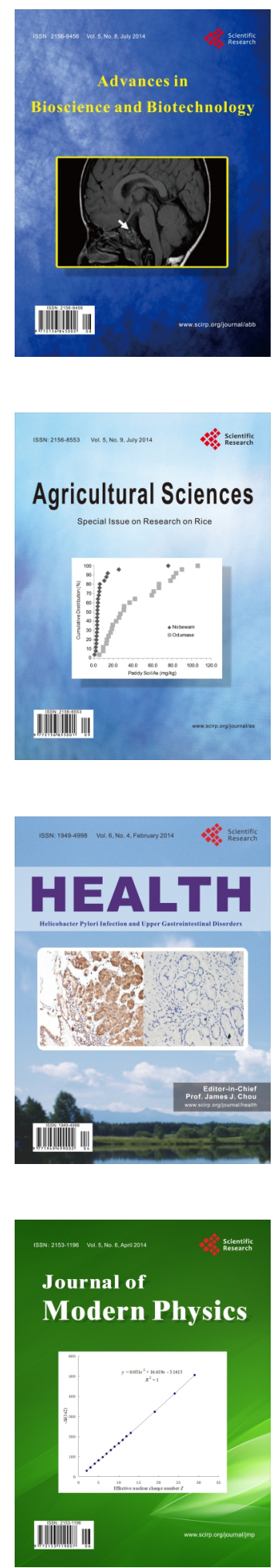
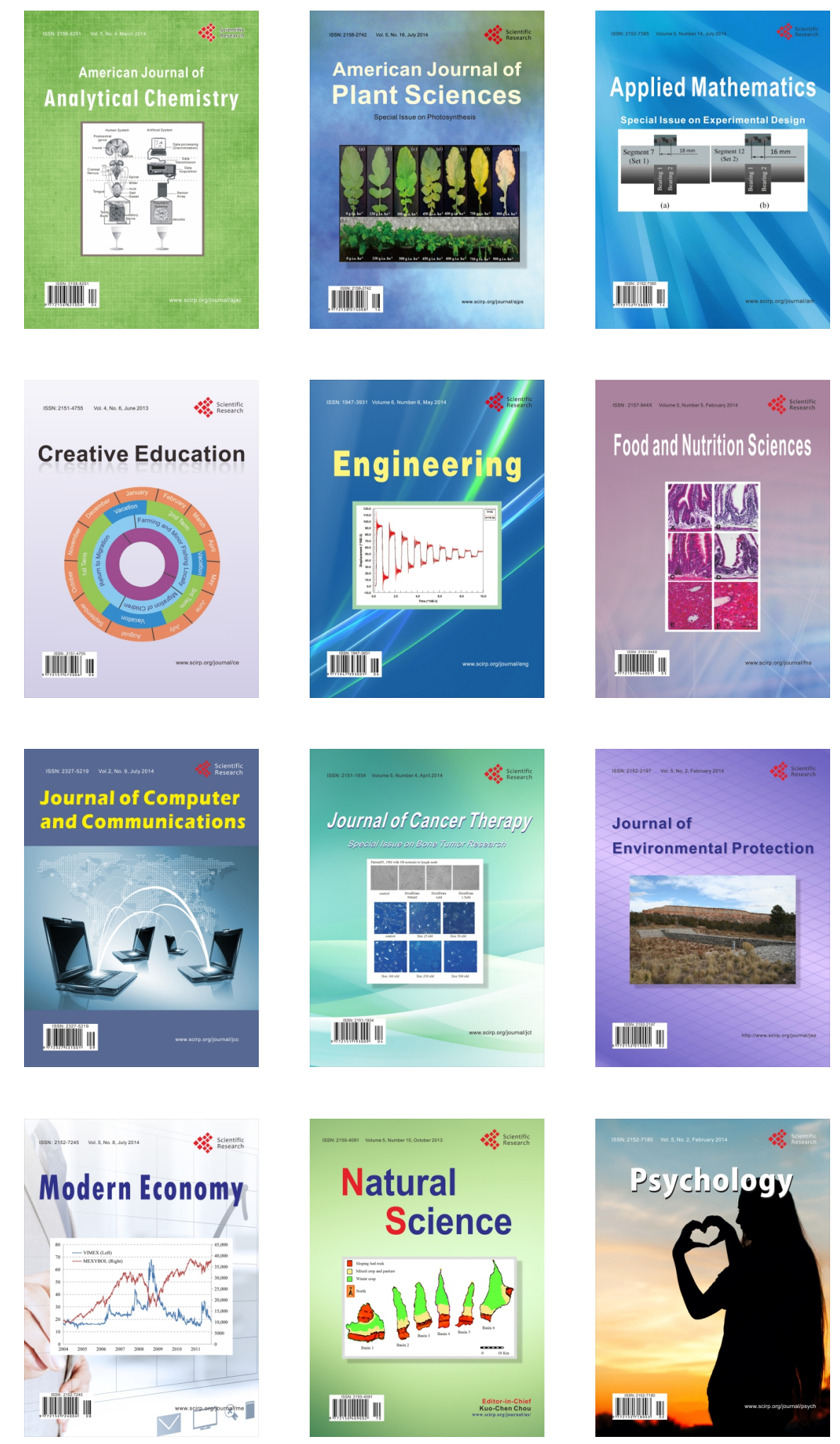